UDC 323.17(478.9)

327.56:351.86(478.9)

DOI: https://doi.org/10.18485/iipe_ria.2020.71.1179.2

Biblid 0543-3657, 71 (2020)

Vol. LXXI, No. 1179, pp. 21-53

review paper

\title{
PERMANENT NEUTRALITY OF THE REPUBLIC OF MOLDOVA-STRATEGY FOR SURVIVAL BETWEEN RUSSIA AND NATO?
}

\author{
Ana JOVIĆ-LAZIĆ, Jovanka KUVEKALOVIĆ-STAMATOVIĆ'
}

\begin{abstract}
The aim of the article is to analyze the main challenges related to the unilaterally declared permanent neutrality of the Republic of Moldova. This decision was made in complicated historical and geopolitical circumstances after the war in Transnistria was "frozen", and foreign forces were deployed on its territory. Permanent neutrality was seen as the best way for Moldova to maintain stability and territorial integrity. Moldova has not yet resolved the "frozen conflict" on its territory. Although the situation has largely stabilized in the meantime with the help of the international community, the division is leading to economic and political instability and carries the risk of new conflicts and tensions. Also, Moldova has not received international recognition of its permanent neutrality status, while the Russian troops continue to infringe its sovereignty and internal security. As a result, questions about the sustainability of that status are increasingly being asked. Despite all the dilemmas, Moldova remains determined to establish permanent neutrality as a basic principle of its foreign and security policy. Permanent neutrality is still considered to be the best way to respond to external influences and internal divisions and thus to preserve the stability and territorial integrity of the country. At the same time, neutral status does not exclude a certain type of security cooperation with Western institutions in order to ensure or, at the very least, implicitly guarantee the security of the state.
\end{abstract}

Keywords: neutrality, Moldova, "frozen conflict”, Transnistria, Russia, NATO, EU.

\footnotetext{
${ }^{1}$ Research Fellow, Institute of International Politics and Economics, Belgrade, E-mail: anajovic@diplomacy.bg.ac.rs

Junior Research Assistant, Institute of International Politics and Economics, Belgrade, E-mail: jovankaks@diplomacy.bg.ac.rs

This paper was created within the scientific project 'Serbia and challenges in international relations in 2020', financed by the Ministry of Education, Science and Technological Development of the Republic of Serbia, and realized by the Institute of International Politics and Economics in 2020.
} 


\section{INTRODUCTORY REMARKS}

Over the course of history, the area in which the Republic of Moldova is located has often been a kind of a playground for key actors on the global stage, and it seems to be the same today. Moldova proclaimed independence in August 1991, as a former federal constituent unit of the Soviet Union. Hostilities between the newly created Republic of Moldova and the Autonomous Region of Transnistria quickly developed into a military confrontation. This ended with the signing of a ceasefire agreement in July 1992. Afterward, the trilateral peacekeeping forces and the Operational Group of Russian Forces were deployed in the security zone along the Dniester River (Ozhiganov, 1997, pp. 183-184). Moldova hoped that declaring permanent neutrality with the Constitution would allow it to defend its territorial integrity and consolidate peace and stability on its territory. Bearing in mind that by declaring permanent neutrality Moldova prohibited the deployment of troops from other states on its territory, it was also perceived as a convenient way of leading to the removal of the Russian military forces from the eastern part of the country and, indirectly, settling the Transnistrian conflict. But more than 25 years later, the Russian troops are still present in Transnistria, challenging Moldova's authority over that part of the country. At the same time, Moldova's unilaterally declared neutrality is not recognized internationally and does not receive sufficient support from the wider international community. It, therefore, raises the issues of relevance, resilience, and sustainability of this status.

Moldova's permanent neutrality cannot be understood unless it considers the actual complexities of its regional and geopolitical status, particularly in light of the expansion of the EU and NATO powers in areas of traditional Russian interest. The issue of Moldova's security is largely intertwined with the complex and conflicting interests and policies of the mentioned actors, which further complicates the situation in the country. In this context, the policy of permanent neutrality can be seen as part of a balanced foreign policy by which Moldova seeks to respond to the internal divisions and external challenges it faces. There is a pragmatic desire of Moldova to avoid tensions and conflicts on its territory, as well as the provocation of Russia at the core of this policy. At the same time, Moldova wants to build national armed forces that will be able to defend the country and enable it to participate in international peacekeeping missions. By contributing to the international system of collective security, Moldova seeks to ensure and improve its national security. In this context, its commitment to developing strong ties and cooperation with the European Union and NATO in the field of security should be seen.

To achieve this, first are presented the basic theoretical assumptions of the concept of neutrality and then an overview of the selected literature - the one 
dealing with the issue of neutrality in general and the one dealing with such a status of Moldova. After that, we look back at the circumstances that led to the decision to declare permanent neutrality by the Constitution. In addition, key documents in the field of foreign policy, national security, and defense are analyzed, which, citing Moldova's commitment to pursue a policy of permanent neutrality, further strengthen the legal basis and define the content of this concept. The internal and external circumstances which determine Moldova's current strategic orientation, the specifics of its permanent neutrality, as well as the challenges and perspectives of its functionality in the contemporary geopolitical context are given particular attention. Consideration is given to the limitations resulting from the lack of foreign recognition of Moldova's military neutrality, as well as the fact that this country is divided by a "frozen" conflict in the Transnistrian region, where the Russian forces have been stationed for years (Kennedy, 2016, p. 524). Such facts are undermining its democracy, territorial integrity, and maneuvering rights in foreign relations. In that context, the specifics of the geopolitical situation in Moldova are analyzed, the character and its foreign policy trends are assessed, and the evolution of its relations with the European Union and NATO is monitored. The possibilities of cooperation with the EU within the Common Security and Defense Policy are highlighted as well as the cooperation developed with NATO within the Partnership for Peace program. Moldova's permanent military neutrality is also observed in the context of Russia's interests, as well as the influence that NATO-Russia relations have on it. The specified objectives of the research determined the concept and influenced the structure of the paper.

\section{NEUTRALITY AS A POLITICAL CONCEPT AND A LITERATURE REVIEW}

Neutrality, like any other, most commonly used political concept, is, as Devine observes, an essentially contested concept (Devine, 2011, p. 335). The understanding of neutrality has changed over time, and the discussion of neutrality is dominated by three views and a theoretical standpoint. In the conventional and realistic understanding, as Joenniemi notes, the emphasis is on "abstinence, isolationism, individualism, and self-sufficiency" Joenniemi, 1989, p. 178). Proponents of this view find very little understanding for neutrality because, as Agius points out, they oppose that stance with the sovereignty and logic of its protection by the use of force, not by refraining from conflict. Referring to Morgentau, Agius further states that realism is dominated by an approach that views neutral states as small, weak, amoral, and passive players in the international system (Agius, 2011, pp. 371-372). In a realistic view, as Beyer and Hoffman note, neutrality is seen as one of two possible foreign policy 
choices, leaving small states with the option of either joining the alliance or declaring neutrality in the hope of being left alone. Therefore, it is assumed that neutrality is a strategy of weak states that are often on the border of the sphere of influence of the superpowers (Beyer \& Hofmann, 2011, p. 287). The second line of thinking about neutrality is a constructivist approach that takes into account ideas, identities and interactions in the international system because it starts from the fact that important aspects are not given to it, but are historically and socially constructed (Agius, 2016, p. 71). Observing the role of neutral states in the process of European integration, Agius underlines their capacity to impact the process positively by contributing to the EU's soft security. It is considered very important that neutral states can contribute to the European security structures thanks to their experience and expertise in special areas (Agius, 2011, p. 381). The concept of neutrality can also be viewed through the prism of institutionalism. Neutrality is seen as an international institution based on norms, rules, and widely understood conventions that regulate the relations between the warring parties and neutral states and thus contribute to international stability. Austin points out that neutrality, which is also an expression of state sovereignty, depends on the influence of institutions, whose role is to determine the scope of the conflict and limit the use of force. Although he does not fundamentally deny the importance of force in state relations, the author concludes that history shows that the institution of neutrality can contribute to international stability in such a way that realism and the use of force cannot (Austin, 1998, pp. 37-56).

Thus, the concept of neutrality is not new and has been sufficiently discussed in the academic and professional literature. However, controversies regarding its essence, whether temporary or permanent, as well as the rights and obligations arising from this status, still exist. Also, the authors analyzed the legal, security, and political aspects of the concept of permanent neutrality of Moldova in order to shed light on the specifics of this concept, which, despite all efforts, remained very contradictory. This research is theoretically supported by publications that generally address the issue of neutrality in areas such as political science, international relations, and international law (Agius, Joenniemi, Beyer, Hofmann, Austin, Andrén, Subedi, Vetschera, Raymond, Karsh, Brian, and others), as well as the work of authors that specifically address the issues of necessity, sustainability, functionality, vulnerability, and sustainability of the Republic of Moldova's status in modern circumstances (Grosso, Burian and Dorul, Cebotari, Vengler, PÎntea, Helly and Panainte, Ungureanu and the others).

For Andrén, neutrality is an elusive concept, both simple and complicated at the same time. He points out that in international law, neutrality means a relationship during the war, and it is defined as a relationship of impartiality taken by third countries towards the warring parties, which is recognized by the warring parties and creates rights and duties between neutral states and warring parties. 
He also states that the state can seek and receive international recognition of the status of permanent neutrality, but also that in peacetime it can unilaterally declare its intention of a general character to remain permanently neutral. However, neither, as Andrén concludes, is an absolute guarantee that the state will not be attacked if war breaks out (Andrén, 1991, p. 69). The simple definition of permanent neutrality given by Subedi is that a state that adopts such a policy must respect the rules of neutrality in all future wars (Subedi, 1993, pp. 241-242). Vetschera points out that a permanently neutral state has an obligation to refrain from starting future conflicts in addition to remaining neutral in the event of a war between two or more states (Vetschera, 1985, p. 52). When it comes to how a neutral state should behave in peacetime, Raymond states, referring to the interpretations of the Swiss government from 1954, that it has obligations not only to refrain from starting a war but also to defend its neutrality by avoiding all activities that could involve it in future conflicts (Raymond, 1997, p. 125).

Analyzing the geopolitical and legal aspects of the status of permanent neutrality, especially of the small states, Karsh states that permanent neutrality is constant non-alignment in peacetime in order to establish the basis for neutrality in wartime, which finally depends on the interests of the warring parties. In that context, he points out that, strategically speaking, the neutrality of a small state can be endangered if a state that wants war is motivated to endanger its territory in order to use it for military or economic purposes. Karsh also declares that the geostrategic position is perhaps the most important limitation of states' survival, since states, unlike people, cannot choose their neighbors. Since their location is constant, they have to find the best ways and means to be on good terms with their neighbors, especially the stronger ones. Thus, as Karsh concludes, the actions and interactions of states, as well as the friendships and enmities between them, are largely determined by the geostrategic reality (Karsh, 2011, pp. 42-81).

Starting from the fact that the territorial aspect, the geopolitical situation, demographic status, and military vulnerability make it difficult for small states to guarantee their own security, Burian and Dorul emphasize that neutrality is their way of survival (Burian \& Dorul, 2016, pp. 61-69). On the other hand, as Pintea, Helly and Panainte point out, despite all the state's efforts to conduct foreign and domestic policy in accordance with the concept of permanent neutrality, history shows that the state cannot avoid the problem of guaranteeing such a status which, in case of war, always depended on the will of the warring parties "weighing the advantages over the disadvantages arising from the violation of this status" (Pintea, Helly \& Panainte, 2011, p. 29).

As Wengler notes, it can be seen from the general principles of international law that other states are not permitted to attack a neutral state in peacetime or expose it to pressure from the threat of attack. However, as he points out, it is 
more important to deny other states the right to put pressure on a neutral state in any way which might jeopardize its neutrality (Wengler, 1964, p. 376).

\section{THE HISTORICAL CONTEXT OF THE DECLARATION OF PERMANENT NEUTRALITY OF MOLDOVA AND THE INTERNAL LEGAL FRAMEWORK OF THIS STATUS}

Understanding the permanent neutrality of Moldova is not possible without knowing the basic reasons that in a certain historical context were behind the policy which resulted in the decision to declare it by the Constitution. The interethnic problems and internal tensions, which later led to the division of Moldova, manifested themselves in the late 1980s when the policy of decentralization caused the release of repressed nationalist sentiments by the majority of the Moldovan-Romanian ethnic population. The increasing trend towards "Romanization" in Moldova has caused local tensions in most multiethnic regions of the country. The law of 1989, which introduced Romanian as the only state language in Moldova (Закон о функционировании языков на территории Молдавской ССР, 1989, ст. 1) ${ }^{2}$ provoked a reaction from the Russophone population that began their own secessionist movements, worried about the loss of status, and encouraged by misinformation from Moscow. The strongest resistance appeared in the region of Transnistria, whose Supreme Council voted to establish a separate state as part of the Soviet Union in September 1990 (Istomin \& Bolgova, 2016, p. 3).

In August 1991, Moldova declared independence, and soon after that, the Chisinau government tried to put Transnistria under its control. This led to a brief armed conflict in 1992, which ended after the intervention of the 14th Soviet Army on the side of the separatists forcing the Moldovan forces to withdraw. ${ }^{3}$ The Agreement on the Principles for a Peaceful Settlement of the Armed Conflict was signed in July 1992, after which the Joint Peacekeeping Forces and the so-called Operational Group of Russian Forces (OGRF) were deployed in the Transnistrian region (Klein, 2019, p. 21).

\footnotetext{
${ }^{2}$ According to Article 1 of this Law, "the state language of the Moldavian SSR is the Moldavian language, which functions on the basis of the Latin alphabet. The Moldovan language as a state language is used in all spheres of political, economic, social, and cultural life and, in this regard, performs the function of the language of interethnic communication on the territory of the Republic". The Moldovan language written in Latin script is actually Romanian, which was also confirmed by the judgment of the Constitutional Court of the Republic of Moldova on December 5, 2013 (Constitutional Court of the Republic of Moldova, 2013).

${ }^{3}$ As Klein stated, after the end of the Second World War, the 14th Army of the Soviet Union was stationed in Transnistria so that it could intervene in Southeast Europe if necessary.
} 
The peace and stability achieved in Moldova in the 1990s were extremely fragile. The conflict in Transnistria was "frozen" with the constant presence of foreign troops (Конституция Республики Молдова, 1994, ст. 11, то. 1, 2). These circumstances, together with the lack of military capabilities, determined Moldova to unilaterally declare the status of permanent neutrality by the Constitution. In Article 11 of the 1994 Constitution, Moldova's permanent neutrality was declared and, accordingly, the deployment of troops of other states on its territory is prohibited. The Constitution also stipulates that the provisions relating to the sovereign, independent and unitary character of the state, as well as provisions on the permanent neutrality of the state, can be amended only by a referendum, with the approval of a majority of citizens registered to vote (Конституция Респуб์лики Молдова, 1994, ст. 142, то. 1). It does not give more details about obligations, rights, or other criteria that arise from the neutrality status, and therefore leaves them to be interpreted by other legal acts. Following its adoption, several key documents in the field of foreign policy and security were adopted, by which Moldova, among other things, reaffirmed its status of permanent neutrality. While the concept of neutrality is not fully articulated, these documents demonstrate the continuity with which Moldova persists in its efforts to uphold the status of neutrality as a fundamental principle of its foreign and security policies.

Foreign Policy Concept adopted in February 1995 states that Moldova pursues a policy of permanent neutrality, pledging not to participate in military conflicts, in politico-military or economic alliances aimed at preparing for war, not allowing the use of its territory to station foreign bases and not own, produce or test nuclear weapons (Республика Молдова Парламент, 1995, ст. 187). The Military Doctrine adopted in the same year states that it is determined by Moldova's foreign and domestic politics and the permanent neutrality proclaimed by the Constitution, and that it has a defensive character only. Moldova does not accept war (except in the case of self-defense) as a means of achieving political objectives. As has been pointed out, it advocates a friendly foreign policy, maintains its military defense without undermining the security of other countries and overall security. In addition, Moldova does not allow its territory to be used for aggressive actions against other states and the deployment of foreign troops, except in cases provided by international agreements on peacekeeping contingents. Potential sources of the military danger include, but are not limited to, other countries' territorial claims, their attempts to interfere in internal affairs to destabilize the country's political situation, and the presence of foreign troops.

The first National Security Concept of Moldova, also introduced in 1995, was replaced with a new Concept in Мay 2008 (Военной доктрине Республики Молдова, 1995, ст. 429). Both documents affirm the provisions of Article 11 of the Constitution, which declares Moldova's permanent neutrality and thus 
states that this country is not a member of military blocs and does not accept the deployment of military forces or arms of other countries and military blocs on its territory. Furthermore, a newer document intends to offer a wider interpretation of the status of permanent neutrality, declaring it as the underlying principle and the cornerstone of the concept of national security. Accordingly, all actions undertaken by Moldova's entire national security system, which aims to ensure national security, are based on this principle. In this regard, as further stated, this country makes efforts to ensure that other subjects of international law respect its declared permanent neutrality (Концепции национальной безопасности Республики Молдова, 2008, ст. 357).

Permanent neutrality has also found its place in the National Security Strategy of Moldova from 2011, which states that this status will be taken into consideration in the process of pursuing national interests. It is then repeated that permanent neutrality presupposes that the state is not a member of military alliances and does not allow the deployment of foreign military troops or weapons of other states and military alliances on its territory (Стратегии национальной безопасности Респуб̆лики Молдова, 2011, ст. 499). At the request of President Igor Dodon, the draft of the new National Security Strategy, prepared in 2016 with the assistance of international partners, was withdrawn from the procedure in June 2017 with a clarification that it did not correspond to the geopolitical reality and was not in line with Moldova's national interests and permanent neutrality (European Commission, 2018, p. 5). In the meantime, in March 2016, the Parliament adopted a political declaration on the inviolability of Moldova's sovereignty, independence, and permanent neutrality. The declaration notes, among other things, that the permanent neutrality declared by the Constitution is not only an indicator of the state's peaceful nature, but also a rational requirement for securing peace and stability in Moldova and the region as a whole. Challenging the constitutional principle of permanent neutrality, as well as actions aimed at its abolition, can be understood as a direct attack on the Constitution, peace, and tranquility of the state, as well as the security of its citizens (Parliament of the Republic of Moldova, 2016).

Two years later, in July 2018, the Parliament adopted the National Defense Strategy and its Action Plan for the period 2018 to 2022, which states that the state's defense policy is affected, among other things, by the status of permanent neutrality established by the Constitution. In addition to repeating that this status implies the non-acceptance of the deployment of troops from other countries on its territory and the renunciation of participation in armed conflicts, it points out that in peacetime neutrality presupposes the building of good friendly relations based on mutual respect and consensus. At the same time, as mentioned, neutrality does not mean isolation, nor does it mean that Moldova will only be a "user of security", but also that it will contribute actively to international security 
through its participation. It was stated that, inter alia, the opportunities for international cooperation will be used to advance the country's national security and defense interests (Национальной стратегии обороны и Плана Аействий по внедрению Национальной стратегии обороны на 2018-2022 годы, 2018, ст. 441). A few months later the Military strategy and its Action plan, which also refers to the period from 2018 to 2022 , were adopted. They also addressed the issue of the permanent neutrality of Moldova. Claiming that the international security environment is characterized by a range of security risks and threats that affect regional security, the Military Strategy underlines that, despite the declared status of permanent neutrality, Moldova must face them. It is also stated that protecting the neutrality status does not exclude, but defines the need for one's own military defense capacities. There is also a clear determination that, in addition to maintaining a neutral status, Moldova cooperates with other countries and international organizations to preserve international peace and security. At the same time, it is concluded that this status will not prevent the examination and acceptance of other international organizations and countries' military experience, as well as cooperation with them in order to develop national military and defense capacities (Правительство Постановление об утверждении Военной стратегии и Плана действий по ее реа^изации на 2018-2022 годы, 2018, ст. 1110).

Therefore, legally speaking, the Constitution adopted in 1994 determined the strategic options of Moldova in a permanent sense. Although it is clear that Moldova's permanent neutrality is unsustainable without real and strict international guarantees of its neutrality, a review of key economic, security, and defense policy documents shows that the country has not given up on pursuing this status as a basic principle of its foreign and security policy (Grosu, 2017, pp. 44-45).

\section{THE INFLUENCE OF THE INTERNAL POLITICAL CONTEXT OF MOLDOVA AND THE ARGUMENTS FOR AND AGAINST ITS POLICY OF PERMANENT NEUTRALITY}

Moldova, one of the poorest countries in Europe, faces systemic corruption, lack of transparency, structural deficits, including the weak institutions. Endemic political instability is illustrated in the difficulty of finding consensus among political parties, unstable coalition governments, frequent early elections, numerous political and financial scandals, anti-government protests. The country is also deeply divided because Moldova has not formed single national consciousness, which is also reflected in the citizens' various orientations and foreign-policy affinities. In these conditions, certain foreign regional actors' geopolitical interests affect the internal political environment and the state's capacity to integrate effectively, which is a factor that further destabilizes Moldova. 
The most pronounced is the influence of Russia, which, with its military, cultural and political presence in Transnistria, as well as its economic ties with Chisinau, remains crucial to Moldova's future stability. The European Union has also become an important factor in Moldova's economic and political development following its enlargement to Romania. It supports Moldova's attempts to establish a stable state as it is situated along the EU borders of Europe, and its fragility can have very negative security implications for the EU itself. The Union is assuming that Moldova can achieve stability by promoting its pro-European orientation. However, this strategy is contrary to Russian interests, which could lead to an increase in social tensions and further destabilization (Kosárová \& Ušiak, 2017, p. 52). As Bitzinger noted in 1991, if an Eastern European country wants to separate itself from Moscow, it should behave in a way that does not call Russia's core security interests into question or automatically weaken them. As he pointed out, it should seek to maintain "neighborly" relations with Russia, while its foreign policy, although not pro-Russian, at least should not be antiRussian (Bitzinger, 1991, pp. 285-287).

Various external actors' strategic influence and conflict of interest are reflected in their support for certain political actors and political parties, divided between pro-European and pro-Russian factions (Heidelberg Institute for International Conflict Research, 2020a, p. 48). ${ }^{4}$ Although the office of the Prime Minister and most of the ministries had been occupied by pro-European party leaders since 2009, with the election of the leader of the Socialist Party in the 2016 presidential election, I. Dodon, the pro-Russian political forces have gained their voice. His choice is partly due to the fact that pro-democracy and proEuropean parties, which had been in power since 2009, had not been able to effectively implement the necessary reforms, and had largely discredited themselves and the entire European integration project (Tudoroiu, 2015, p. 655). At the same time, the election of Dodon marked a shift in foreign policy priorities and an increase in Russian influence in Moldova (Lins de Albuquerque \& Hedenskog, 2016, p. 16). ${ }^{5}$

\footnotetext{
${ }^{4}$ More than 20,000 supporters of the pro-Russian Socialist Party demonstrated on November 18, 2018, in Chisinau, demanding that Moldova become a member of the Eurasian Economic Union and cancel the Association Agreement signed in 2014 with the EU. Earlier, in early February 2018, at least 10 local councils symbolically supported reunification with Romania, while the following month, about 10,000 demonstrators gathered in downtown Chisinau on the same occasion.

${ }^{5}$ During the election campaign, I. Dodon advocated the renewal of economic ties with Russia, the cancellation of the Association Agreement with the EU. He also suggested that Moldova should be federalized, in a similar way as Russia once proposed (Kozak Memorandum). As for the permanent military neutrality of Moldova, I. Dodon called for the formation of a trilateral commission of the USA, the EU, and Russia, which would guarantee the inviolability of this status.
} 
Due to the difficulty of finding a compromise between the political parties, mainly the pro-Russian Socialist Party on the one hand and the pro-European ruling parties on the other, instability soon shifted to the state level (Heidelberg Institute for International Conflict Research, 2018, p. 55). In 2018, the Supreme Court of Moldova temporarily suspended President I. Dodon's powers three times because he led to an institutional blockade by refusing to appoint new ministers to the Government and to sign laws (Heidelberg Institute for International Conflict Research, 2020a, p. 55). The internal political crisis continued in the year 2019. At the parliamentary elections held in late February 2019, the pro-Russian Socialist Party won the most seats, 35 out of 101, followed by the Democratic Party and the pro-European ACUM bloc. The elections were held in line with the current controversial mixed electoral system, which replaced the old proportional system. ${ }^{6}$ The Government changed twice in 2019. In June, a coalition of ACUM and the Socialist Party succeeded the Democratic-led government. Just five months later, on November 12, the Socialist Party deputies backed by the Democratic Party deputies voted for no-confidence against the Government (Emerson \& Cenusa, 2018, pp. 15-16). ${ }^{7}$ On 14 November 2019, Dodon appointed a new minority government, headed by Ion Chicu, as an independent candidate (Heidelberg Institute for International Conflict Research, 2020b, p. 48).

The politicization of governmental institutions has severely undermined the credibility of democracy and the rule of law in Moldova. According to Cenusa, the change in the electoral system is one more proof that a corrupt approach to governance prevails in Moldova because the political interests of the parties are more important than the public and national interests (Cenusa, 2017). In the circumstances of open political disputes, corruption, and inefficiency of the Government and other state institutions, Moldova cannot implement the necessary reforms effectively. In addition to being politically fragile and economically weak, Moldova is exposed to the influence of various external actors who are trying to attain their interests in the region. Compared to Moldova, they have greater cultural, political, and military potential and rely on large ethnic groups which then show separatist tendencies.

Referring to Ukraine, Ciurea stresses that neutrality must not always be an effective means to achieve stability. Neutrality has not prevented the annexation of Crimea and the war at Donbas, as the author points out. The solution, he says, would be to join NATO as an alliance strong enough to respond to Russia

\footnotetext{
${ }^{6}$ Critics of the new electoral system point out that it favors large and developed political parties.

${ }^{7}$ The founder of the Democratic Party is the oligarch in exile Vladimir Plathoniuc, who is believed to have been preventing an effective anti-corruption campaign for years.
} 
(Ciurea, 2015). Dungaciu claims that prolonging Moldova's neutral status is a mistake, having in mind that this status is definitely inaccurate since, as he points out, foreign troops are still stationed on its territory. Of course, as he concludes, this process should be managed carefully and intelligently, always taking into consideration the development of events in the eastern part of the country (Dungaciu, 2015, p. 42). For Ungureanu, permanent neutrality generates multidimensional instability, which is why it needs to be examined in the context of the new threats, risks, and vulnerabilities that this country is facing (Ungureanu, 2017, pp. 116-137). Burian and Dorul view things differently. They point out that any sudden change in foreign policy could lead to a reaction from different ethnic groups, which could also jeopardize Moldova's territorial integrity. Also, they advocate the independence and individuality of foreign policy, as well as the maintenance of its permanent neutrality. They interpret neutrality as a kind of guarantee of the absence of any foreign interference which, as they claim, should guarantee the independence of Moldova's foreign policy and allow it to cooperate with all countries around the world. Burian and Dorul believe that if neutral states increase their credibility and convince the international community of their neutrality, they will exclude the possibility of its infringement (Burian \& Dorul, pp. 61-70).

Recently there have been noticeable attempts by Moldova to explicitly call for international acceptance of a permanent neutrality status. Moldova's president, I. Dodon, addressed the General Assembly of the United Nations on 26 September 2019, requesting de facto recognition and respect for this status. He underlined that the Constitution had proclaimed permanent neutrality, as well as that any effort to challenge it would deepen internal disputes and divisions. This, as he also said, also undermined any possibility of finding a solution to the "frozen" conflict in Transnistria and, indirectly, improving peace and security across the region. I. Dodon also referred to Austria's neutrality. However, the status of Moldova's neutrality was proclaimed in circumstances when that country already had a "frozen conflict" and foreign troops on its territory, while Austria's permanent neutrality was proclaimed after the last foreign soldier left its territory (Rendl, 1998, p. 162). ${ }^{8}$ Having regard to the pro-Russian orientation of the political party of the Moldovan President, his speech was criticized on the grounds that he stated Russia's position, which promotes Moldova's permanent neutrality due to fear of further NATO expansion to the East (Socor, 2019).

\footnotetext{
${ }^{8}$ In contrast to Moldova, the permanent neutrality of Austria was negotiated and agreed at the international level. The withdrawal of allied forces was agreed upon as part of those negotiations. The whole process was closely linked to the re-establishment of an independent and democratic Austria.
} 
Given the poor economic situation of Moldova, permanent neutrality should allow it to work closely with neighboring countries and the West and maintain good relations with Russia. This is also seen as an opportunity to, without political preferences, cooperate with different foreign markets to encourage and develop a very weak national economy. Neutrality also relieves Moldova of its obligation to invest significant economic resources to consolidate its system of defense. As Viotti noted in 1990, neutral states have considerably lower costs for not having to maintain a large, permanent army. Such a political position helps them to protect their territorial integrity and sovereignty, relying above all on the overall atmosphere of East-West relations (Viotti, 1990, p. 5).

So, in order to understand the nature of the permanent neutrality of Moldova, we should keep in mind that this country is placed between two opposing security structures, the Euro-Atlantic area of NATO and the sphere of interest of Russia. These actors have a major impact on Moldova's internal political situation, and therefore on its foreign policy. In these circumstances, the security of the state can be achieved only through a balanced foreign policy that will take into account the complex contradictions of the interests of the EU, NATO, and Russia in the region.

\section{RELATIONS BETWEEN MOLDOVA AND RUSSIA AND THE PLACE OF ITS PERMANENT NEUTRALITY}

Since declaring independence, Moldova has hesitated to stay close to Russia, primarily due to Russia's unique position in handling the Transnistrian conflict. Moldova refused to accede to the Treaty of Collective Security of 15 May 1992, even before its Constitution declared permanent neutrality. And although it participated in the work of the Commonwealth of Independent States, it did not sign air defense and joint border protection agreements that were adopted within this organization. The status of neutrality was supposed, among other things, to serve as an argument for the withdrawal of the Russian armed forces and security equipment from the eastern part of the country. However, they are still present in this region against the will of Moldova, which is why their current relations can be viewed through the lens of the "frozen conflict" in Transnistria. It is important to start from the fact that Russia's approach to the issue of unrecognized states as a whole, as well as Transnistria, is based on the principles of pragmatism and directly depends on its national and geopolitical interests. According to Fischer, Russia is a major foreign player and mediator in all peace processes, but at the same time, its military presence and political participation make it a side of the conflict (Fischer, 2016, p. 9). With the help of the so-called Operational Group of Russian Forces, as well as participation in the Joint Peacekeeping Force, Russia provides the necessary support for the functioning 
of Transnistria. However, it is characteristic that the independence of this selfproclaimed republic was not officially recognized by Russia itself (Rusakovich, 2016; Евразийское Приднестровье, 2014). ${ }^{9}$

As Sizov claims, the reasons for that are of a geopolitical, foreign, and economic nature. Moreover, Russia is satisfied with the scope and status of its military forces in Transnistria and is not ready for further deterioration of relations with the West. The fact that Transnistria does not border Russia plays an important role in Russia's cautious stance, so its recognition would be impractical and would only complicate the situation further, without the possibility of providing absolute support and protection (Сизов, 2017, стр. 126-127).

Transnistria also has a symbolic significance for Russia because it has historically attached great strategic and economic significance to the Black Sea region. Russia is also using its military presence to prevent Moldova and other post-Soviet countries from turning their foreign policies towards Euro-Atlantic integration. In that context, keeping Moldova's permanent military neutrality is in Russia's interest, which is why Russia is promoting it on an international level. In April 2008, Russia appealed to Moldova's military neutrality at the NATO Summit in Bucharest when it came to a potential invitation to Ukraine and Georgia to enter into NATO membership negotiations (Makarychev, 2010, p. 3). As Friedman once remarked, in the hands of NATO or some other Western power, Moldova might become a tool against Russia. Russia, as this author further points out, understands this clearly and does all it can to create a pro-Russian state in Moldova, or at least unstable enough that no one can use it to threaten the Russians (Friedman, 2010). That NATO enlargement to the East is an important security issue for Russia indicates Russian Foreign Minister Sergei Lavrov's statement from October 2014. In the statement, he said that Transnistria would have the right to political self-determination if Moldova renounced its permanent neutrality status (Ofitserov-Belskiy \& Sushenstov, 2018, p 287).

However, a neutral status in itself is not enough for Russia, but it also needs real levers of influence, thanks to which it could shape Moldova's foreign policy, not only in the short-term but also in the long-term. In that context, when it comes to resolving the conflict in Transnistria, Russia has its own interests and is determined to realize them. It wants to keep up the key role in reaching an agreement, as well as to stay the main external "guarantor" of the agreement by continuing its military presence (Karniewicz, Petrovická \& Wunsch, 2010, p. 6). Through an unbalanced constitutional arrangement predicted by the Kozak Memorandum, Moscow tried to impose a political solution that would ensure

\footnotetext{
${ }^{9}$ Russia's annexation of Crimea has strengthened the arguments for Transnistria's accession to Russia. In mid-April 2014, the Transnistrian Supreme Council called on the Russian leadership to decide on its recognition as a sovereign independent state.
} 
the continuation of the Russian military presence and influence on the creation of Moldova's domestic and foreign policy (Ofitserov-Belskiy \& Sushenstov, 2018, p. 286).

The national security of Moldova is closely linked to regional security. With the outbreak of the Ukrainian crisis, the situation in Donbas and Crimea began to impact Transnistria and, consequently, Moldova. There have been fears that Russia plans to take control of the entire Southeast of Ukraine to secure access to Transnistria and the strategically important Black Sea region. In May 2015, Kyiv suspended the agreement on land transport, which reduced the danger that Moscow would use Transnistria as a base for potential offensive actions in Moldova or the opening of another front in Western Ukraine (Klein, 2019, p. 26). Besides the deteriorating regional security situation, Moldova has also faced increasing influence from Russia. Furthermore, Russia's military involvement, resources, and logistical funding have guaranteed Transnistria's existence for years (Popescu, 2005, p. 24). Now Russia is beginning to conduct joint exercises together with the troops in this breakaway region. This is contrary to its official policy of supporting Moldova's permanent neutrality status. Instead of securing demilitarization, Russia is striving to maintain and strengthen its military presence in the east of the country.

In 2017, Moldova's parliament adopted a resolution calling for the Russian troops to be withdrawn from its territory. The document stressed that the existence and strengthening of Russia's military force in the eastern part of the country are in infringement of constitutional provisions, especially as regards Moldova's freedom, territorial integrity, and permanent neutrality, as well as the principles of international law. Russian ammunition, weapons, and military equipment on the territory of Moldova are cited as a constant threat to regional and European security and stability in general. In this context, the international community is called upon to support the initiative to keep the sovereignty, independence, territorial integrity, and neutrality of Moldova (Parliament of the Republic of Moldova, 2017). However, the Operational Group of Russian Forces conducted a joint military exercise with the troops of Transnistria again. Moldova called on Russia to withdraw its forces, and a few months later, in June 2018, it submitted a draft of the resolution to the UN General Assembly calling on Russia to immediately and unconditionally withdraw troops and arms from Moldova (General Assembly UN, 2018). Presenting the draft resolution, the Minister noted that the Russian forces were stationed in the eastern part of his country without its consent. These are, as he pointed out, the principles of sovereignty and territorial integrity, stressing that the proposed resolution is not, in any way, an offer for confrontation, nor is it intended to politicize this issue. Before the resolution was put to the vote, the Russian representative suggested postponing the consideration of the draft, noting that the text was not the result of the 
preliminary consultations and that Moldova itself was divided on this issue (UN, 2018). Despite the UN resolution, the Russian and Transnistrian troops continued to conduct joint military exercises (Heidelberg Institute for International Conflict Research, 2020a). ${ }^{10}$

The National defense strategy adopted in 2018 also opposes the Russian military presence in Transnistria. There is a considerable military capacity of the separatist armed troops in Transnistria, which is said to be supported from abroad. It is further pointed out that the Russian military formations are illegally on the territory of Moldova, contrary to the Constitution of that country. These separatist and foreign troops, as noted, have significant operational capabilities and are capable of forming intervention forces at any time. Their military capability would empower the government on the left bank of the Dniester and Russia to achieve its geopolitical goals, which is why it presents a significant threat to the sovereignty and territorial integrity of Moldova. Given Russia's policy towards the West and some neighboring countries, including Moldova, it is expected that its influence will continue and grow through diplomatic, cultural, educational, economic and military pressures, spreading of disinformation, and even political corruption. It was concluded, however, that Moldova intends to continue an open, transparent dialog with Russia to find solutions to issues of common interest, including the withdrawal of the Russian armed forces and the destruction and/or evacuation of stockpiles of ammunition stored on its territory (Постановление об утверждении Национальной Dастратегии обороны и П^ана Аействий по внедрению Национальной стратегии обороны на 20182022 годы, 2018).

The danger of hostile use of military and paramilitary formations from the left bank of the Dniester was recognized as a threat in the Military Strategy of Moldova adopted in October 2018. The possibility of using these forces to incite, spread and provoke conflicts based on interethnic, historical, religious, social, and other differences to destabilize Moldovan society, as pointed out, represents a serious military threat to the country's security. There are fears that in the given international context, these forces could be used to destabilize the situation in the entire region. In addition to infringing Moldova's neutrality status, the presence of the Russian troops is said to nurture military potential and give military support to the regime on the left bank of the Dniester. This obviously violates the provisions of the Agreement on the Principles for the Peaceful Settlement of Armed Conflicts, according to which the Russian troops must

\footnotetext{
${ }^{10}$ Evidence of internal divisions soon arrived from Moldova itself, after the resolution was criticized by pro-Russian President I. Dodon. He also reiterated on September 18, 2018, that the Russian forces should stay in Transnistria until the final solution to the conflict is reached.
} 
keep neutrality. Given the current tensions between Russia and Ukraine, it was concluded that they might be a source of regional destabilization. ${ }^{11}$ The risk of the spread of the Ukrainian conflict and the zone of instability to the borders of Moldova was also recognized as a military threat. In these circumstances, as has been pointed out further, certain extremist-oriented social groups, including illegal armed groups on the Dniester's left bank, may be encouraged to launch

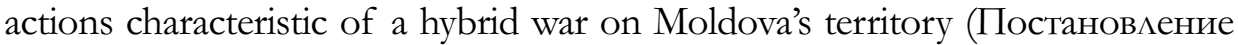
об утвержАении Военной стратегии и ПАанадействий по ее реализации на 2018-2022 годы, 2018).

Thus, Moldova disputes the legitimacy of the Russian presence and demands that Moscow withdraws its soldiers from that region, in line with the commitments made at the OSCE Istanbul Summit in 1999. Nevertheless, despite Chisinau's aforementioned complaints, there are opinions that the Russian military presence not only provided the necessary security guarantees of Transnistria, but also that this is the main reason why there were no major military conflicts in the region after the "freezing." The withdrawal of the Russian troops is seen as part of a wider security arrangement in Europe that can be implemented as part of the settlement of the dispute between Chisinau and Tiraspol (Istomin \& Bolgova, 2016, p. 3). As Beyer and Wolff note, Russia's influence in Moldova is part of a bigger geopolitical game in which the "frozen conflict" in Transnistria has significant instrumental value. Furthermore, Russia's long-standing presence, Transnistria's financial reliance, and the cultural and social inclination of the majority of its citizens to Moscow have, over time, established and strengthened Russia's position in the region. With this support, Transnistria has, over time, consolidated into a kind of self-governing territorial entity, which has some of the attributes traditionally associated with a sovereign state. These include a functioning government, a military force of its own, a permanent population, and effective control of the territory. Furthermore, unlike the rest of Moldova, Transnistria has never been part of the cultural space of Romania, and its inhabitants rely on Russia as the protector of their cultural identity (Beyer \& Wolff, 2016, p. 339). Russia, as Nuriyev points out, has always considered itself a great power to be surrounded by semi-sovereign buffer states. Even today, Russia plays a key role in the security situation in the entire post-Soviet region, while all recent political steps by Russia are also aimed at strengthening its position in this part of the world (Nuriyev, 2018, pp. 6-19). Despite these obstacles, Moldova insists that Russian soldiers should be replaced by members of the peacekeeping forces (Jović-Lazić, 2015, p. 239). At the same time, all activities

\footnotetext{
${ }^{11}$ According to the agreement of July 21, 1992, in addition to the OGRV, there is a Russian contingent on the left bank of the Dniester as part of the Joint Peacekeeping Force. This strategy, as it is pointed out, makes a difference between those two military units.
} 
that are undertaken in the interests of national security, Moldova seeks to implement in accordance with the principles of permanent military neutrality (Manolache \& Trofimov, 2013, pp. 14-28).

\section{COOPERATION BETWEEN THE REPUBLIC OF MOLDOVA AND THE EUROPEAN UNION IN THE FIELD OF FOREIGN AND SECURITY POLICY AND ITS PERMANENT NEUTRALITY}

Since becoming independent, Moldova has declared its affiliation to Europe and, therefore, its wish to move forward on the path of European integration. The competition in the post-Soviet space between Russia and the West had also periodically had a negative impact on the atmosphere in Moldova, but the involvement of the international community in that country was very limited for a long time. Nevertheless, expecting Moldova to become its neighbor after enlargement to Romania, the Union's approach has become more proactive. The Union, therefore, sent representatives to the negotiations on the status of Transnistria for the first time in 2002. The EU and the United States agreed that the implementation of the proposed Kozak Memorandum would effectively make it possible for Transnistria and thus Russia to paralyze any new government, veto key foreign policy decisions and keep the Russian troops in Transnistria. The EU and US officials soon put strong pressure on the then-president of Moldova, Vladimir Voronin, to drop the deal (Beyer \& Wolff, 2016, pp. 339-340).

In an effort to maintain stability at its new borders, the European Neighborhood Policy (ENP) was formulated by the Union in 2004. In that context, the EU has recognized the strategic role of Moldova and the frozen conflict in Transnistria as a serious threat to its security. The growing interest of the Union in the region has increased its presence in Moldova. An EU special representative has been appointed and a European Commission delegation has been set up in Chisinau. In late 2005, the European Union also launched the Border Assistance Mission (EUBAM) in Moldova and Ukraine, with the aim of contributing to the stabilization of the region by increasing security at the Moldovan-Ukrainian border (Dura, 2009, p. 276). ${ }^{12}$ As observers, the European Union and the United States have been participating in negotiations to resolve the 'frozen conflict' in Transnistria (the so-called $5+2$ format) since October 2005 (OSCE). ${ }^{13}$

${ }^{12}$ This mission is deployed to respond to smuggling and trafficking of drugs, weapons, and people across Moldova's eastern border with Ukraine, especially along the part controlled by the Transnistrian authorities. It is also believed that by reducing illegal revenues and creating conditions for Transnistria to be integrated into Moldova's customs area, this mission can contribute to a peaceful resolution of the conflict.

${ }^{13}$ Since 2005, the European Union and the United States have joined a five-member negotiating team composed of representatives of the opposing parties (Moldova and Transnistria), 
The fact that the frozen conflict poses a major challenge to regional security, along with Chisinau's interest in establishing close cooperation with the EU, has over time put dialogue on security and defense issues on the agenda. Cooperation within the EU's Common Security and Defense Policy (CSDP) between the Union and the so-called partner countries implies their participation in EU missions and operations (Pintea, Helly \& Panainte, 2011, p. 39). Moldova has consistently demonstrated its willingness to cooperate with the EU in this sector while keeping a permanent neutrality status. The concept of Moldova's national security from 2008 sees participation in the CSDP missions as an important aspect of the development of bilateral political relations with the EU and a factor that indirectly contributes to increasing Moldova's security on the European continent. It is also explicitly mentioned that, in its national security policy, Moldova is guided by the principle of respect for the status of permanent neutrality (Закон об утверждении Концепции национальной безопасности Республики, 2008).

Over time, Moldova has taken important steps to strengthen its ties with the $\mathrm{EU}$ in the area of the CSDP. The Working Group for CSDP as the main interinstitutional body with the task to plan and coordinate capacities for participation in operations, missions, and related activities and to give recommendations for improving cooperation with the EU in this area was established by Moldova in 2010. The 2011 National Security Strategy states that Moldova's close relations with the EU member states include the maintenance of active, constructive dialogue, the exchange of experience, the implementation of joint projects, the application of European standards, and security practices. It is, therefore, highlighted that the process of European integration should give the necessary instruments for the defense and promotion of the state's national interests and that Moldova's national security cannot be imagined outside the context of European security. In order to improve national and regional stability, attention should be given to intensifying cooperation with the EU in the field of the Common Foreign and Security Policy and the Common Security and Defense Policy. Moldova is ready to cooperate with the EU on conflict prevention and resolution, crisis management, and non-proliferation of weapons of mass destruction (Постановление об утвержАении Стратегии национальной безопасности Республика Молдова, 2011). The Framework Agreement Moldova's Participation in EU Crisis Management Operations was signed in 2012.

mediators (OSCE, the Russian Federation, and Ukraine) as observers. The goal of the $5+2$ talks is to establish the parameters of a comprehensive solution based on the sovereignty and territorial integrity of the Republic of Moldova within its internationally recognized borders, with the special status of Transnistria within Moldova. About the progress of the negotiations see more in: https://www.osce.org/mission-to-moldova/119488. 
It has been in force since July 2013 (Council Decision, 2012; Agreement, 2013). The following year, in June 2014, Moldova and the EU signed an Association Agreement which provides, inter alia, for intensive political dialogue and strengthening practical cooperation in the field of conflict prevention and crisis management. By participating in civilian and military crisis management operations, as well as in certain Union exercises and training, Moldova is expected to contribute to international security and crisis management, both regionally and globally (Association Agreement, 2014).

In order to establish a legal framework for the fulfillment of obligations undertaken in the framework of agreements concluded with the EU and other international organizations, Moldova adopted the Law on participation in international missions and operations in 2015 (Закон об участии Республики Молдова в межАународных миссиях и операциях, 2015). So far, Moldova has contributed by sending experts to the EU Security Force Training Mission in Mali (EUTM Mali) and the EU Military Advisory Mission to the Central African Republic (EUMAM RCA). Moldova sent the first delegate to the position of an expert on gender problems and human rights in the Mali mission in 2014, and its military specialist was sent to the Central African Republic the following year, where he took the place of the liaison officer. During 2016 and 2017, one expert from Moldova was in the EU mission in Mali, and after October 2018, there were two (DG NEAR, 2017, p. 5). In 2017, Moldova and the EU concluded an Agreement on security procedures for exchanging and protecting classified information, which further sets out the general conditions for its participation in EU operations (Agreement, 2017).

The principles of participation of Moldova in international peacekeeping operations derive from its neutral status, basic national interests, and international obligations. As mentioned in the Introduction to the National Defense Strategy from 2018, Moldova aspires to EU integration and, therefore, to the approximation to European principles and values. As it opens up new possibilities for cooperation, the Global Strategy for the European Union's Foreign and Security Policy, which seeks to establish a pan-European security system, is seen as a document of particular importance to member states and partner countries. Finally, Moldova appreciates the commitment of the European Union to support a peaceful solution to the Transnistrian conflict and expresses its willingness to increase its contribution to international missions and operations under the auspices of the EU, the UN, and the OSCE (Постановление об утверждении Национальной стратегии обороны и Плана действий по внеАрению Национальной стратегии обороны на 2018-2022 годы, 2018).

Moldova's overall contribution to peacekeeping missions remains very modest as it undergoes a period of modernization of the armed forces, has a limited budget, and faces internal security constraints. However, given that, in the context 
of European integration aspirations and the Association Agreement, Moldova has concluded an agreement establishing a framework for participation in EU crisis management operations, and its participation in Union-led missions is expected to increase.

The status of permanent neutrality is not in conflict with the CSDP of the European Union. By working closely with the EU, as Subedi points out, neutral states do not lose the freedom to act in order to protect the vital national and foreign policy interests needed to maintain that status (Subedi, 1993, p. 245). Furthermore, by participating in the CSDP, neutral states strengthen their position and capacity to respond more effectively to modern security challenges (Subedi, 1995, pp. 399-412).

\section{MOLDOVA'S COOPERATION WITH NATO IN THE FIELD OF SECURITY AND THE PLACE OF ITS PERMANENT NEUTRALITY}

After Moldova's independence, a comprehensive reform of the security sector and the modernization of the armed forces were needed to ensure the security and defense of the country. In view of the lack of economic potential, Moldova, in cooperation with NATO, has seen an opportunity to gain support to strengthen national institutions and move closer to Euro-Atlantic standards in this field. Bearing in mind that NATO has a long history of cooperation with neutral countries or ones that do not aspire to membership, that commitment was not in conflict with the constitutionally declared neutrality of Moldova.

Relations with NATO were established in 1992 when Moldova joined the North Atlantic Cooperation Council. ${ }^{14}$ Bilateral cooperation was established on 16 March 1994 with Moldova's accession to the Partnership for Peace (PfP). At the signing ceremony, the then President underscored Moldova's policy of neutrality, emphasizing that his country does not belong to the military structures of the CIS and that joining the PfP does not open up the possibility of membership of NATO. At the same time, he expressed confidence that participation in the PfP program would help strengthen Moldova's territorial integrity, political independence, and national security. The following year, in 1995, the Individual Partnership Program (IPP) was adopted as a framework for Moldova's participation in the Partnership for Peace. Although Moldova's membership in the Partnership for Peace was mostly of a formal nature during this period, in the summer of 1996, Moldovan troops for the first time

\footnotetext{
${ }^{14}$ This forum for dialogue was inherited in 1997 by the Euro-Atlantic Partnership Council, which brings together all allies and partner countries in the Euro-Atlantic area.
} 
participated in the PfP "Peace Shield 96" maneuvers in Ukraine and "Cooperative Determination 96" in Bulgaria. The first PfP exercises were held in Moldova in May 1997 (Waters, 1998, pp. 81-84). In the same year, the National Army of Moldova joined the PfP Planning and Review Process (PARP). After that, Moldova agreed with all the official goals for achieving interoperability of national forces with NATO forces, in order to participate in multinational operations. In 1997, Moldova established permanent contact with NATO after the country's ambassador to Belgium had become a representative of NATO (Molodilo, 2013, p. 35). Two years later, on May 11, 1999, the 22nd Peace Battalion was established as the first unit of the Moldovan Armed Forces compliant with NATO standards with the task of participating in international peacekeeping operations and humanitarian missions. Since then, members of the 22nd Battalion have participated as military observers in international operations in Ukraine, Romania, Bulgaria, Albania, Macedonia, Armenia, Germany, Sweden, and the United States, as well as in UN missions in Liberia, Ivory Coast, Sudan, and South Sudan (MOD RM, 2016).

The concept of the Individual Partnership Action Plans (IAPP) was introduced at the 2002 NATO Summit in Prague with a vision of deepening ties between NATO and partner countries. The adoption of the Moldova-NATO Individual Partnership Action Plan on 19 May 2006 marked a more intensive form of cooperation that created the conditions for regular and structured dialogue, including dialogue at the political level. This document clearly states that cooperation with NATO is based on respect for the permanent neutrality of Moldova. It is further noted that as a neutral country, Moldova is implementing the IAPP with the goal of deepening cooperation with European and EuroAtlantic structures and institutions, improving the reform process, and modernizing its national security and defense sector, strengthening democratic control of the military, etc. The issue of cooperation with NATO is also mentioned in the 2008 Concept of National Security of Moldova. Considering that Moldova does not aim to join NATO, its relations with this organization, as has been stated, have the character of pragmatic relations, while respecting its constitutional principle of permanent neutrality. Moldova's 2011 National Security Strategy also devotes space to cooperation with NATO (Закон об утверждении Концепции национальной безопасности Республиики, 2008). This cooperation is, as has been stated, implemented within the boundaries of the Partnership for Peace, the Euro-Atlantic Partnership Council, and, in practice, in accordance with the Moldova-NATO Individual Action Plan. In this way, Moldova contributes to the consolidation of European security and stability, which in turn, as it is pointed out, has a positive impact on its national security. Such a strategy is expected to ensure the transformation of Moldova from a customer to a source of regional security and stability, and its further participation 
in the PfP and the Euro-Atlantic Partnership Council will allow it to incorporate and apply foreign experience to reform the security and defense sector. It is particularly stressed that cooperation with NATO does not affect Moldova's status of permanent neutrality and does not go beyond the constitutional framework. It further states that through the process of deepening cooperation with NATO, achieved in 2006 with the launch of the Individual Partnership Action Plan (IAPP), Moldova aims to acquire the necessary tools and practices for building a functioning national security sector capable of dealing with new and conventional threats and risks. It is said that the IAPP is related to the reform of the national security sector in accordance with European standards and practices in the field of security. As concluded in this document, Moldova should use cooperation with NATO to strengthen national capacities with a view to preventing and managing crisis situations and their consequences (Постановление об утвержАении Стратегии национальной безопасности Республики Молдова, 2011).

A liaison office for NATO opened in Chisinau in 2017. In the same year, the Individual Partnership Action Plan between Moldova and NATO was adopted, which defined the priority areas and common goals of cooperation in the next two years. It is envisaged that a number of actions will be taken to reform and modernize the security sector, develop the armed forces, strengthen defense capabilities, and combat new security threats. These include organizing political consultations on security and defense issues, continuing to participate in the NATO peacekeeping operation in Kosovo (KFOR) to enhance the interoperability of the national armed forces and contributing to the promotion of security and stability in Europe, capitalizing on NATO's peace and security program assistance and capacity building for emergency response and crisis management (GRM, 2017). It is important to note that this document pays attention to the neutrality of Moldova, too. Namely, it is explicitly mentioned that during the period of implementation of this document, Moldova must carry out its activities in compliance with the Constitutional Court's decision on the interpretation of Article 11 of the Constitution on the country's permanent neutrality. The decision, released on May 2, 2017, states that the Republic of Moldova's involvement in collective security structures, such as the United Nations security system, peacekeeping operations, humanitarian operations, those seeking to enforce joint sanctions on aggressors and those infringing international law, is not contrary to the neutrality status of the country (IPAP, 2017). So far, cooperation with non-NATO countries has indicated the potential that neutral states may have for the development of an international system of collective security.

Moldova's readiness to intensify and deepen relations with NATO, while respecting the status of permanent neutrality, was also confirmed in the 2018 National Defense Strategy. It points out that the development of regional and 
international events has conditioned the consolidation, development, and modernization of the defense system as an urgent need and a strategic imperative of national importance, requiring considerable efforts to achieve conceptualnormative and practical adaptation. Among other things, Moldova's national interests are related to its participation in ensuring international security. Cooperation with NATO is observed in this context and states that it has been developed in different fields and aspects, starting with education and science, development of defense capabilities (for example, Defence and Related Security Capacity Building (DCB) Initiative), military exercises, disaster management, raising levels of interoperability until the implementation of projects for the development of the defense system (Постановление об утверждении Национальной стратегии обороны и Плана действий по внеАрению Национальной стратегии обороны на 2018-2022 годы, 2018).

Thus, Moldova's cooperation with NATO has increased over time as the Alliance has expanded and provided increasing assistance to modernize the Moldovan army in line with NATO standards. Moldova has seen an opportunity in this cooperation to strengthen its security and create conditions for its army to contribute to international peacekeeping missions. To date, more than 40 Moldovan troops, with UN approval, have participated in NATO-led multinational operations. These included the NATO Training Mission in Iraq and NATO-led Mission in Bosnia and Herzegovina (SFOR). Moldova acquired the status of NATO's "operational partner" for the mission in Kosovo (KFOR) in 2012. Among others, the KFOR mission was supported by the Moldovan Platoon Infantry Manoeuvre and the Explosive Ordnance Disposal Unit (NATO, 2018). Based on the above, it seems that the position expressed by Waters in 1998 has not lost its relevance. As the author points out, the Moldovan government is always ready to recognize the benefits of participating in the Partnership for Peace, highlighting that cooperation with NATO is not contrary to its policy of permanent neutrality. At the same time, as he further notes, it also clearly indicates that a neutral status prevents Moldova from participating in military structures under Russian leadership (Waters, 1998, p. 84).

\section{CONCLUDING REMARKS}

Since gaining independence, Moldova has faced a number of challenges that it has, among other things, tried to address by unilaterally declaring its permanent neutrality with the Constitution. Despite the "freezing" of the conflict on its territory, permanent neutrality was seen as the most effective way to protect the sovereignty and territorial integrity. It was also intended to serve as a further argument for the withdrawal of Russian soldiers and military equipment from Transnistria. Due to the great division of Moldovan society, constant neutrality 
was expected to help its reintegration. Notwithstanding drastic changes in the spectrum of powers on the world stage, the explanations given are still valid today.

A balanced foreign policy is in Moldova's national security interest, while permanent neutrality can be seen as a strategy for the survival of the country and the most appropriate way of reducing additional external and internal political pressures. Viewed from the outside, Moldova constitutes a buffer zone between key geopolitical players, with the danger of becoming a geopolitical battlefield. Its position is, therefore, very complex and it is influenced, on the one hand, by various interests of NATO and the West in general, and, on the other, Russia. The current situation in the region, caused by the Ukrainian crisis, further increases security risks in Moldova itself. Seen from the inside, the unresolved conflict in Transnistria is a constant source of tension, and together with Russia's military presence in the region represents a major obstacle to the country's sustainable military neutrality.

Russia wants to stay a key factor in Transnistria, despite international commitments to withdraw its troops, as well as strong objections from Moldova. It is trying to keep direct power and control in the region. At the same time, Russia has requested international recognition of Moldova's neutrality in its attempts to limit Western activities in its sphere of influence and, above all, in its fear of further expansion of NATO to the East. However, this status is internally challenged by the existence of the Russian armed forces and defense equipment in Transnistria, and it reduces the possibilities for it to be recognized and guaranteed at the International level.

In addition, the status of permanent neutrality is the basis for Moldova's national security policy being institutionalized. Moldova insists on respecting this status in its relations with other countries and international organizations. In all key documents that this country has signed, both with NATO and the EU, the principle of permanent neutrality is set out. Moldova wants to present itself as a reliable partner in the maintenance and strengthening of international peace and security, which is why it participates in the international peacekeeping missions of the UN, the EU, the OSCE, and in NATO missions when there is a UN mandate. This gives it the ability to benefit from the other neutral countries' experiences, while the national army has the opportunity to achieve a greater degree of professionalism and operational experience. The importance of the above is huge, keeping in mind that Moldova has a very small budget for a defense that does not meet its army's needs, as well as its security problems, risks, and threats.

Due to the risk of instability in the region, the International community must make more efforts to create the conditions for Moldova to support its policy of permanent neutrality and overcome many challenges it faces. The most important of them is certainly resolving the "frozen conflict" in Transnistria. Additionally, 
as Rumer notes, relations with Russia remain an essential element of the economic, political, and security equations of Moldova. Moldova cannot risk poor relations with Russia, and it should be carefully handled. As this author states, neither the European Union nor the United States are capable of replacing Russia in that equation. Careful balancing between Russia and the West is key to the future of Moldova, and to suggest anything else could have serious consequences for this country (Rumer, 2017).

\section{REFERENCES}

Agius, C. (2011). Transformed beyond recognition? Politics of post-neutrality, Cooperation and Conflict, 46(3), pp. 370-395.

Agius, C. (2013). Social Constructivism, in: Collins A. (Ed.), Contemporary Security Studies (pp. 87-103). Oxford, Oxford University Press.

Agreement between the European Union and the Republic of Moldova establishing a framework for the participation of the Republic of Moldova in European Union crisis management operations, Official Journal of the European Union. L 008/2 (2013).

Agreement between the European Union and the Republic of Moldova on security procedures for exchanging and protecting classified information, Official Journal of European union. L 106/3 (2017).

Andrén, N. (1991). On the Meaning and Uses of Neutrality, Cooperation and Conflict, 26(2), pp. 67-83.

Association Agreement between the European Union and the European Atomic Energy Community and their Member States, of the one part, and the Republic of Moldova, of the other part, Official Journal of the European Union. L 260/4 (2014).

Austin, A. D. (1998). Realism, Institutions, and neutrality: constraining conflict through the force of norms, Commonvealth: A Journal of Political Science, 9, pp. 37-56.

Beyer, J. L., \& Hofmann, S. C. (2011). Varieties of neutrality: Norm revision and decline, Cooperation and Conflict, 46(3), pp. 285-311.

Beyer, J., \& Wolff, S. (2016). Linkage and leverage effects on Moldova's Transnistria problem, East European Politics, 32(3), pp. 335-354.

Bitzinger, R. A. (1991). Neutrality for Eastern Europe: Problems and Prospects, Bulletin of Peace Proposals, 22(3), pp. 281-289.

Burian, A., \& Dorul, O. (2016). Permanent Neutrality of the Republic of Moldova in the Context of European Geopolitics, Tamkang Journal of International Affairs, 7, pp. 61-94. 
Cenusa, D. (2017). Geopolitical Games Expected Ahead of Moldova's 2018 Elections. The Foreign Policy Research Institute, retrieved from https://www.fpri. org/article/2017/10/geopolitical-games-expected-ahead-moldovas-2018 elections/. Accessed 10/04/2020.

Constitutional Court of the Republic of Moldova (2013) "The text of the Declaration of Independence prevails over the text of the Constitution", 05.12.2013, retrieved from http://constcourt.md/libview.php?l=en\&idc= 7\&id=512\&t $=/$ Overview $/$ Press-Service/News/The-text-of-the-Declaration -of-Independence-prevails-over-the-text-of-the-Constitution.Accessed 25/05/2020.

Corneliu, C. (2015). The Nentrality of the Republic of Moldova in the Light of Ukraine's Security Policy. Policy Paper, Foreign Policy Association (APE), Chisinau. Retrieved from http://old.ape.md/public/publications/2214152_en_cc_ ukraine_neu.pdf.

Council Decision 2013/12/CFSP of 25 October 2012 on the signing and conclusion of the Agreement between the European Union and the Republic of Moldova establishing a framework for the participation of the Republic of Moldova in European Union crisis management operations, Official Journal of the European Union. L 008/1 (2013).

Devine, K. (2011). Neutrality and the development of the European Union's common security and defence policy: Compatible or competing?, Cooperation and Conflict, 46(3), pp. 334-369.

Dungaciu, D. (2015). Geopolitics and Security by the Black Sea: The Strategic Options of Romania and Republic of Moldova, in: Vaduva S. \& Thomas A. R. (Eds.), Geopolitics, Development, and National Security: Romania and Moldova at the Crossroads (pp. 23-51). Cham, Springer.

Dura, G. (2009). EUBAM Moldova-Ukraine, in: Grevi G., Helly D. \& Keohane D. (Eds.), European Security and Defence Policy: the first ten years (1999-2009) (pp. 275-287). Paris, European Institute for Security Studies.

Emerson, M., \& Cenusa, D. (2016). Deepening EU-Moldovan relations: What, Why and How? London, Rowman \& Littlefield International.

Fischer, S. (2016). Russian Policy in the Unresolved Conflicts, in: Fischer S. (Ed.), Not Frozen! The unresolved conflict over Transnistria, Abkhazia, South Ossetia and Nagorno-Karabakh in Light of the Crisis over Ukraine (pp. 9-24). Berlin, Stiftung Wissenschaft und Politik.

Friedman, G. (19 November 2010). Geopolitical Journey, Part 4: Moldova, Stratfor, retrieved from https://worldview.stratfor.com/article/geopoliticaljourney-part-4-moldova. Accessed 10/04/2020. 
General Assembly Adopts Texts Urging Troop Withdraw from Republic of Moldova. (22 June 2018), retrieved from https://www.un.org/press/ en/2018/ga12030.doc.htm. Accessed 25/05/2020.

General Assembly of United Nations. (22 June 2018). Draft Resolution A/72/L.58 Complete and unconditional withdrawal of foreign military forces from the territory of the Republic of Moldova, New York.

Grosu, R. (2017). The Concept of Permanent Neutrality of the Republic of Moldova from the Point of View of Discrepancies between Judicial Norms and Geopolitical Uncertainties, Cross-Border Journal for International Studies, 2(2), pp. 45-63.

Heidelberg Institute for International Conflict Research. (2018). Conflict Barometer 2017.

Heidelberg Institute for International Conflict Research. (2020a). Conflict Barometer 2018.

Heidelberg Institute for International Conflict Research. (2020b). Conflict Barometer 2019.

Istomin, I., \& Bolgova, I. (2016). Transnistrian strategy in the context of RussianUkrainian relations: the rise and failure of 'dual alignment', Southeast European and Black Sea Studies, 16(1), pp. 169-194.

Joenniemi, P. (1989). The Peace Potential of Neutrality: A Discursive Approach, Bulletin of Peace Proposals, 20(2), pp. 175-182.

Jović-Lazić, A. (2015). Odnosi izmedu Evropske unije $i$ Ruske Federacije: kraj XX $i$ početak XXI veka. Beograd, Institut za međunarodnu politiku i privredu.

Karniewicz, T., Petrovická, M., \& Wunsch, N. (2010). The EU and Conflict Resolution in Transnistria. Policy Paper, Publisher New Dimensions of Security in Europe.

Karsh, E. (2011). Neutrality and Small States. London, Routledge.

Kennedy, R. (2016). The limits of soft balancing: the frozen conflict in Transnistria and the challenge to EU and NATO strategy, Small Wars \& Insurgencies, 27(3), pp. 512-537.

Klein, M. (2019). Russia's Military Policy in the Post-Soviet Space: Aims, Instruments and Perspectives, Research Paper 1. Berlin, Stiftung Wissenschaft und Politik.

Kosárová, D., \& Ušiak, J. (2017). The Republic of Moldova as a Potential Failing State?, Journal of Vasyl Stefanyk Precarpathian National University, 4(34), pp. 50-59.

Lins de Albuquerque, A. L., \& Hedenskog, J. (2016). Moldova A Defence Sector Reform Assessment. Retrieved from https://www.foi.se/rest-api/report/ FOI-R-4350-SE. 
Makarychev, A. (2010). Russia's Moldova Policy: Soft Power at the Service of Realpolitik?, in: Welt C. \& Schmemann A. (Eds.), After the Color Revolutions, Political Change and Democracy Promotion in Eurasia: Policy Perspectives (pp. 51-56). Washington, The Institute for European, Russian and Eurasian Studies, Elliott School of International Affairs, The George Washington University.

Manolache, C., \& Trofimov, V. (2013). Establishment and Evolution of the National Security of the Republic of Moldova, Revista Militara, 9(1), pp. 14-28.

Nuriyev, E. (2018). Endless Endgame: Whither Russia-West Confrontation?, Russia in Global Affairs, retrieved from https://eng.globalaffairs.ru/articles/ endless-endgame-whither-russia-west-confrontation/. Accessed 15/04/2020.

Ofitserov-Belskiy, D., \& Sushenstov, A. (2018). Central and Eastern Europe, in: Tsygankov A. P. (Ed.), Routledge Handbook of Russian Foreign Policy (pp. 282295). London, Routledge.

Ozhiganov, E. (1997). The Republic of Moldova: Transdniester and the 14th Army, in: Georgievich Arbatov A., Lynn-Jones M. S. \& Motley K. (Eds.), Managing Conflict in the Former Soviet Union: Russian and American Perspectives (pp. 145-210). Cambridge, MIT Press.

Parliament of the Republic of Moldova. (2016). Decision No.47 of 31.03.2016 for the approval of the Declaration of the Parliament of the Republic of Moldova regarding the inviolability of the sovereignty, independence and permanent neutrality of the Republic of Moldova, Chisinau.

Parliament of the Republic of Moldova. (2017). Declaration of the Parliament of the Republic of Moldova on the withdrawal of Russian military forces from the territory of the country, Chisinau.

Parliament of the Republic of Moldova. (21 July 2017). Declaration of the Parliament of the Republic of Moldova on the withdrawal of Russian military forces from the territory of the country. Retrieved from http:// www.parlament.md/LinkClick.aspx? fileticket $=\mathrm{dMw} 6 \mathrm{DKaOFzU} \% 3 \mathrm{D} \&$ tabid=90\&language $=$ ro-RO. Accessed 10/04/2020.

Pîntea, I., Helly, D., \& Panainte, P. (2011). Prospects for Moldova's cooperation within the Common Security and Defence Policy. Chisinau, Soros Foundation.

Popescu, N. (2005). The EU in Moldova: Settling Conflicts in the Neighbourbood, Occasional Paper, No. 60. Paris, European Union Institute for Security Studies.

Raymond, A. G. (1997). Neutrality Norms and the Balance of Power, Cooperation and Conflict, 32(2), pp. 123-146.

Rendl, A. (1998). Neutrality and the EU: an Austrian view, in: L. Goetschel (Ed.), Small States Inside and Outside the European Union (pp. 161-168). Boston, Springer. 
Rumer, E. (2017). Moldova between Russia and the West: A Delicate Balance, Carnegie Endowment for International Peace, retrieved from https://carnegie endowment.org/2017/05/23/moldova-between-russia-and-west-delicatebalance-pub-70056. Accessed 20/05/2020.

Rusakovich, A.V. (2016). The Change in the Geopolitical Situation in the former Soviet Union after 2014, in: Douhan A. F. \& Rusakovich A. V. (Eds.), Collective Security Treaty Organization and Contingency Planning after 2014 (pp. 5-35). Geneva - Minsk, The Geneva Centre for the Democratic Control of Armed Forces.

Socor, V. (2019). President Dodon Introduces Nuances to Moldova's Neutrality. Eurasia Daily Monitor, 16(134), retrieved from https://jamestown.org/ program/president-dodon-introduces-nuances-to-moldovas-neutrality/. Accessed 15/04/2020.

Subedi, S. P. (1993). Neutrality in a Changing World: European Neutral States and the European Community, The International and Comparative Law Quarterly, 42(2), pp. 238-268.

Subedi, S. P. (1995). The Common Foreign and Security Policy of the European Union and Neutrality: Towards Co-Existence?, Netherlands International Law Review, 42(3), pp. 399-412.

Tudoroiu, T. (2015). Democracy and state capture in Moldova, Democratization, 22(4), pp. 655-678.

Ungureanu, V. (2017). A Geopolitical Approach to the National Security of the Republic of Moldova in the Context of the Interferences of the Geostrategic Relations of the Great Powers, Cross-Border Journal for International Studies, 2(1), pp. 116-137.

Vetschera, H. (1985). Neutrality and defense: Legal theory and military practice in the European neutrals' defense policies, Defense Analysis, 1(1), pp. 51-64.

Viotti, P. R. (1990). Comparative Neutrality in Europe, Defense Analysis, 6(1), pp. 3-15.

Wengler, W. (1964). The Meaning of Neutrality in Peacetime, McGill Law Journal, 10(4), pp. 369-379.

European Commission. (3 April 2018). Association Implementation Report on Moldova, Joint Staff Working Document. European Commission - High Representative of the Union for Foreign Affairs and Security Policy, SWD 94.

Закон Nr. 219 от 03.12.2015 об участии Республики Молдова в межАународных миссиях и операциях, Monitorul Oficial. Nr. 25-30, статья №. 57 (2016).

Закон № 112 от 22-05-2008 об утверждении Концепции национальной безопасности Республики Молдова, Monitorul Oficial. № 97-98 статья № 357 (2008). 
Обращение Верховного Совета Приднестровской МолАавской Республики к Презиленту Российской Федерации. (16 Апреля 2014). Евразийское Приднестровье, retrieved from http://eurasian.su/news/obrashchenieverhovnogo-soveta. Accessed 20/05/2020.

Республика Молдова Парламент. (1989). Закон № 3465 от 01-09-1989 о функционировании языков на территории Молдавской ССР, Vestile R.s.s.m № 9 статья № 217, 30-09-1989, Кишинэу, ст. 1.

Республика Молдова Парламент. (2018). Постановление № 134 от 19-072018 об утверждении Национальной стратегии обороны и Плана Аействий по внеАрению Национальной стратегии обороны на 20182022 годы, Monitorul Oficial, № 285-294 статья № 441, 5 Августейший, Кишинэу.

Респубиика Молдова Парламент. (2018). Правительство Постановление № 961 от 03-10-2018 об утвержАении Военной стратегии и П^анадействий по ее реализации на 2018-2022 годы, Monitorul Oficial, № 410-415 статья № 1110, 2 Ноябрь, Кишинэу.

Республика Молдова Парламент. (14 Октября 2011). Постановление № 153 от 15-07-2011 об утверждении Стратегии национальной безопасности Республики Молдова, Monitorul Oficial, № 170-175 статья № 499.

Республика Молдова Парламент. (14 Июль 1995). Постановление № 482от 06-06-1995 о Военной доктрине Республики Молдова, Monitorul Oficial, № 38-39, статья № 429.

Республика Молдова Парламент. (29 Июль 1994). Конституция Республики Молдова, Monitorul Oficial, Nr. 1, Статья 11 (1), (2).

Респубиика Молдова Парламент. (6 Апреля 1995). Постановление № 368 от 08-02-1995 об утверждении Концепции внешней политики Республики Молдова, Monitorul Oficial, № 20, статья № 187.

Сизов, С. Г. (2017). Непризнанные государства на постсоветском пространстве и позиция России, Вестник Омского университета. Серия «Исторические науки», 1(13), С. 124-128.

(DG NEAR, 2017): The Consolidation of Inter-institutional Cooperation and Communication Mechanism on CSDP-related Matters Case Study: Republic of Moldova, Public Study Report, Directorate General for Neighborhood and Enlargement Negotiations.

(GORM, 2017): New possibilities for Moldova - NATO partnership development. Government of the Republic of Moldova, retrieved from https://gov.md/en/content/new-possibilities-moldova-nato-partnershipdevelopment. Accessed 10/04/2020. 
(IPAP, 2017): Individual Partnership Action Plan (IPAP) Republic of MoldovaNATO for 2017-2019. Retrieved from https://mfa.gov.md/sites/ default/files/2017-2019_an_ipap_en.pdf. Accessed 14/04/2020.

(MOD RM, 2016): 22nd Peacekeeping Battalion - 17 Years of Performance (photo \& video). Ministry of Defence of the Republic of Moldova, retrieved from https: / $/$ www.army.md/?lng $=3 \&$ action $=$ show\&cat $=122 \& o b j=3819$. Accessed 15/04/2020.

(NATO, 2018): Relations with the Republic of Moldova. (12 October 2018). Retrieved from https://www.nato.int/cps/en/natohq/topics_49727.htm. Accessed 15/04/2020.

(OSCE, 2020): Press Releases and statements related to the $5+2$ negotiations on the Transdniestrian settlement process. Retrieved from https://www.osce.org /mission-to-moldova/119488. Accessed 12/04/2020. 


\section{STALNA NEUTRALNOST REPUBLIKE MOLDAVIJE - STRATEGIJA ZA OPSTANAK IZMEĐU RUSIJE I NATO?}

Apstrakt: Cilj članka je da analizira glavne izazove povezane sa jednostrano proglašenom trajnom neutralnošću Republike Moldavije. Ova odluka je doneta u komplikovanim istorijskim $\mathrm{i}$ geopolitičkim okolnostima, nakon što je rat $\mathrm{u}$ Pridnjestrovlju „zamrznut”, a strane oružane snage raspoređene na njenoj teritoriji. Stalna neutralnost se videla kao najbolji način da Moldavija očuva stabilnost i teritorijalni integritet. Moldavija još uvek nije rešila „zamrznuti sukob" na svojoj teritoriji. Iako se u međuvremenu situacija u velikoj meri stabilizovala uz pomoć međunarodne zajednice, podela dovodi do ekonomskih i političkih nestabilnosti i nosi rizik od novih sukoba i napetosti. Takođe, Moldavija nije dobila međunarodno priznanje svog statusa stalne neutralnosti, dok ruske trupe i dalje krše njen suverenitet i unutrašnju bezbednost. Kao rezultat, sve se češće se postavljaju pitanja o održivosti tog statusa. Uprkos svim dilemama, Moldavija je i dalje odlučna da uspostavi stalnu neutralnost kao osnovno načelo svoje spoljne i bezbednosne politike. Stalna neutralnost se i dalje smatra najboljim načinom da se odgovori na spoljne uticaje i unutrašnje podele i tako doprinese očuvanju stabilnosti i teritorijalnog integriteta zemlje. Istovremeno, neutralni status ne isključuje određenu vrstu bezbednosne saradnje sa zapadnim institucijama kako bi se osigurala, ili u najmanju ruku, implicitno garantovala bezbednost države.

Kjučne rě̌i: neutralnost, Moldavija, "zamrznuti konflikt", Pridnjestrovlje, Rusija, EU, NATO.

Received: $17 / 7 / 2020$

Accepted: $7 / 8 / 2020$ 